University of Nebraska - Lincoln

DigitalCommons@University of Nebraska - Lincoln

Papers in Plant Pathology

Plant Pathology Department

2010

Upper Canopy Collection and Identification of Grapevines (Vitis) from Selected Forests in the Southeastern United States

Sydney E. Everhart

University of Nebraska-Lincoln, everhart@unl.edu

Follow this and additional works at: http://digitalcommons.unl.edu/plantpathpapers

Part of the Other Plant Sciences Commons, Plant Biology Commons, and the Plant Pathology Commons

Everhart, Sydney E., "Upper Canopy Collection and Identification of Grapevines (Vitis) from Selected Forests in the Southeastern United States" (2010). Papers in Plant Pathology. 364.

http://digitalcommons.unl.edu/plantpathpapers/364

This Article is brought to you for free and open access by the Plant Pathology Department at DigitalCommons@University of Nebraska - Lincoln. It has been accepted for inclusion in Papers in Plant Pathology by an authorized administrator of DigitalCommons@University of Nebraska - Lincoln. 


\title{
Upper Canopy Collection and Identification of Grapevines (Vitis) from Selected Forests in the Southeastern United States
}

\author{
Sydney E. Everhart* \\ Department of Biology and Earth Science, University of Central Missouri, Warrensburg, \\ Missouri 64093
}

\begin{abstract}
Woody grapevines (Vitis spp.) are common in the deciduous forests of the southeastern United States. Their growth habit makes leaf collection challenging and polymorphic leaves make identification of species difficult. Mature grapevines can grow up to $48 \mathrm{~cm}$ in diameter at breast height and reach the upper canopy of trees more than $35 \mathrm{~m}$ in height. Leaf morphology is the most readily available character used for species identification. However, most mature grapevines do not produce leaves below the upper canopy and if they do, these leaves are morphologically indistinguishable from other species. In order to sample leaves from mature grapevines, the doubled rope climbing method was used to access the canopy in Great Smoky Mountains National Park in Tennessee, Daniel Boone National Forest and Berea College Forest in Kentucky, and Ha Ha Tonka State Park in Missouri. Leaf voucher specimens were collected from the upper canopy and used to create a modified key to species for those regions. The purposes of this paper are to report a new method for collecting grapevine leaf vouchers from the upper canopy of trees, to present a modified key used for identifying dried leaf vouchers of Vitis species, and to present a discussion of the possible utility of this research for future studies.
\end{abstract}

INTRODUCTION Grapevines (Vitis L.) are in the order Rhamnales in the family Vitaceae. Grapevines are dicotyledonous, deciduous, perennial plants that can live for many years and can grow more than $35 \mathrm{~m}$ tall when supported by an adjacent tree. A grapevine is a liana (woody climber) that climbs by wrapping long thin tendrils around a support. Grapevines develop woody, flaky bark as they get older. The flowers are dioecious, greenish, and borne only on new shoots that arise from dormant buds formed on the previous season's growth. They are also polygamodioecious, which means that they are essentially dioecious, but also having some bisexual flowers present in some or all plants. Consequently, both flower sexes are needed for precise species identification (Moore 1985).

\footnotetext{
*email address: ever77@uga.edu

Present address: Department of Plant Pathology, University of Georgia, 2105 Miller Plant Science Building, Athens, Georgia 30602-7274.

Received November 8, 2008; Accepted May 28, 2009.
}

The genus Vitis is made up of species predominantly found in the temperate regions of the Northern Hemisphere, including North America and Asia, and a few species in the tropics (Gleason and Cronquist 1991). There are approximately 60 species of Vitis naturally occurring in the United States, with $V$. aestivalis, $V$. cinerea, and $V$. vulpina as the most commonly occurring in the southeastern United States (Stupka 1964, Jones 2005).

The fruit of several Vitis species, including $V$. vinifera, $V$. labrusca, $V$. aestivalis, $V$. rotundifolia, and their hybrids, have been cultivated for commercial production in vineyards for consumption as fresh table grapes, dried as raisins, produced into juices, and for fermentation into wine (This et al. 2006). Grape leaves are considered edible and are used in the production of dolmades (stuffed grapevine leaves). Native North American grapes have been important to the grape production industry worldwide since the late 1800's when the indigenous phylloxera root louse (Daktulo- 
sphaira vitifoliae Fitch) became a worldwide pest of cultivated grapes. Native North American grapes offered more resistant rootstocks that could be grafted to cultivars used in production. In addition to resistance against pests like the phylloxera root louse, native species offer resistance against diseases caused by root nematodes, fungi, and bacteria (Read and Gu 2003).

Despite the economic importance of native North American grape species to the commercial grape industry, they are a relatively understudied group of species. The most recent taxonomic work on North American Vitis species was based on living or freshly collected specimens and difficult to apply to dried herbarium specimens most often used in ecological studies (Moore 1991). Although leaves of Vitis species are the most commonly available morphological character for species identification, sampling leaves of canopy climbing grapevines growing in mature forest is complicated because they rarely produce leaves within reaching distance in the canopy understory.

Current ecological research on Vitis in temperate forests of North America either limit identification of canopy climbers to genus (Morrissey et al. 2009) or focus only on shrubby, understory grapevines (Collins and Wein 1993). In many cases, understory sucker shoots of canopy climbing grapevines are polymorphic and not suitable for identification, so the only way to identify these individuals is to propagate live cuttings in the greenhouse or field plots (Moore 1985). The drawbacks to these methods are that: 1.) information gathered from plants identified to genus is incomplete and cannot be compared across studies, 2.) collections limited to non-canopy climbers means sampling will give preference to certain species and disturbed habitats within the forest, such as the forest edge, and near streams or roads, and 3.) propagating grape plants from cuttings is time consuming, sometimes difficult, and would still exclude sampling climbing vines that do not produce twigs within reaching distance. Therefore, the purpose of this paper is to report a new method for collecting grapevine leaf vouchers from the upper canopy, present a modified key used for identifying dried leaf vouchers, and discuss these applications for future studies of Vitis species in mature forests.

\section{METHODS}

Study Areas

Great Smoky Mountains National Park in Tennessee, Daniel Boone National Forest and Berea College Forest in Kentucky, and $\mathrm{Ha} \mathrm{Ha}$ Tonka State Park in Missouri were selected for this study because of favorable climatic conditions, variety of habitats, and high diversity of tree and vine species (Stupka 1964, Jones 2005).

Great Smoky Mountains National Park (GSMNP) covers an area approximately 210,545 ha (est. 1930) and is located on the North Carolina and Tennessee border, at the southern-most range of the Appalachian mountain chain. The geology of this region is highly variable but metamorphosed sandstone is the dominant rock type, with interspersed regions of slate, mafic, and ultramafic rock, with limestone underneath (Southworth et al. 2005). The average yearly rainfall is 140 $216 \mathrm{~cm}$ (Shanks 1954). Settled in pioneer times (1700's), logging began in the early $20^{\text {th }}$ century and continued until 1939. Approximately $40 \%$ of the GSMNP was inaccessible and has remained virgin, old growth forest. The park encompasses $965 \mathrm{~km}$ of trails, many streams and waterfalls, much of which is only accessible by footpaths (Cohen 2000). Typical dominant tree species within most of GSMNP are yellow-poplar (Liriodendron tulipifera L.), eastern hemlock [Tsuga canadensis (L.) Carr.], and a variety of oak species (Quercus spp.). The understory often includes a thick cover of rhododendron (Rhododendron spp.). Up to 1940, American chestnut (Castanea dentata L.) was the dominant tree species until the fungal pathogen [Cryphonectria parasitica (Murrill) Barr] causing chestnut blight was introduced from Europe and decimated American chestnut populations in North America. Grapevines are also recorded in the area, with a record size grapevine, thought to be Vitis vulpina L., $48 \mathrm{~cm}$ diameter at breast height (DBH, $1.5 \mathrm{~m}$ ) documented near Dunns Creek, GSMNP, in 1935. This is one of six species of Vitis that are known to occur in GSMNP (Stupka 1964).

Daniel Boone National Forest (DBNF) extends northwest to southeast in eastern Kentucky to the Tennessee border, and spans $225 \mathrm{~km}$ on the eastern edge of the Cumberland Plateau. Major rock types of the Cumberland Plateau are conglomeritic sandstone, siltstone, shale, and coal. These rocks are of 
the Pennsylvanian period and are underlain by shale, limestone, and dolomite rock of the Mississippian. Coal and petroleum are important natural resources in this area. Established as Cumberland National Forest in 1937, the name was changed to Daniel Boone National Forest in 1965 and today covers an extensive, rugged area of over 258,440 hectares, including the Clifty Wilderness Area to the east (5,000 hectares), Beaver Creek Wilderness Area (2,000 hectares), and Red River Gorge Geological Area (10,500 hectares) (Collins 1975). Located within 21 counties, DBNF is mostly forested and is characterized by sandstone cliffs, bluffs, caves, arches, and natural bridges. The forest type is within the mixedmesophytic region of the eastern deciduous forest with tree species such as yellow-poplar (Liriodendron tulipifera), hickory (Carya spp.), maple (Acer spp.), and eastern hemlock. Protected within DBNF are more than 750 species of flowering plants and 170 species of moss (Hopkins 1996). Precipitation in Kentucky varies from the north to south, from 104-135 cm per year (Martin et al. 1993), making it drier than GSMNP.

Berea College Forest (BCF) is privately owned and managed by Berea College, Berea, Kentucky. The forest is located to the east of DBNF, also on the edge of the Cumberland Plateau. The physical features and vegetation are similar to those of DBNF. Most of the 3,200 hectares was acquired by Berea College between 1898 and 1960 and was in poor condition due to heavy logging, farming, and grazing. The area was reforested by the college and is now managed for recreation, water, wildlife, and wood. The college uses the area for educational purposes and wood for craft production (Perry 2000).

Ha Ha Tonka State Park (HAT) is 1,091 hectares, dedicated as a state park in 1978 and located in the Ozarks region of Southeast Missouri. The vegetation of HAT is characterized by a patchy combination of mixed mesophytic woodlands and oak savanna on karst topography. The combination of thick limestone bedrock and acidic water has created numerous geologic features throughout this part of Missouri. The karst area of HAT was created when a cave system collapsed and created numerous sinkholes, rocky outcroppings, and a natural bridge. In 1981,
28 hectares were designated as a karst natural area by the state of Missouri and 386 hectares were designated as a savanna natural area. The savanna area consists of high-quality, dry chert woodland and sandstone savanna with dolomite glades, which supports a high diversity of native prairie and woodland species, including Vitis species (Webb 2004).

\section{Field Methods}

Field expeditions were conducted during the summer of 2006 in HAT during 15-19 May, in GSMNP during 1-13; 25-29 June, 1-9 August, and in DBNF and BCF during 15-23 June, 1830 July. The primary objective of this research was to collect bark samples from living trees and grapevines as part of a tree canopy study of corticolous myxomycetes (true slime molds), bryophytes, and lichens (Everhart et al. 2008). Grapevines were chosen because they have a high diversity of myxomycetes on their bark and their growth habit allowed comparison of bark samples taken in a vertical transect from the neighboring tree and grapevine.

The doubled rope climbing method was used to access the tree canopy (Jepson 2000, Kilgore et al. 2008), where canopy was defined as three meters above the ground to the tops of living trees (Snell and Keller 2003). Trees suitable for climbing that also supported a grapevine were difficult to locate. Trail guides, vegetation maps, and questioning local residents, park and state officials, and hikers on the trail were all used to locate suitable trees. After locating trees with grapevines, the selection criteria for bark sampling were trees with minimum DBH $60 \mathrm{~cm}$ and grapevines with DBH minimum $4 \mathrm{~cm}$. These selection criteria excluded many trees that allowed bark sampling higher than $15 \mathrm{~m}$ because either a suitable climbing tree had a grapevine that was too small for sampling bark or the tree with a large grapevine was not suitable for climbing. For these reasons, completely random selection of trees with grapevines was not possible. Any suitable climbing tree with a grapevine that had a DBH greater than $4 \mathrm{~cm}$ was climbed and sampling bark from more than two trees with grapevines per day was considered a successful sampling day.

\section{Upper Canopy Leaf Collection}

In order to identify species of grapevines that were being sampled, leaf voucher specimens 
were collected from the upper canopy of the grapevine for identification. The doubled rope climbing method was preferred over other methods for accessing the tree canopy, such as using a ladder, climbing spurs, and the single-rope climbing technique. The doubled rope climbing method allowed all equipment to be easily carried in backpacks by the climbing team, it did no permanent damage to the trees, and it allowed the climber to advance the climbing rope to higher branches within the tree and access the top of the tree.

Tree climbing is a potentially hazardous activity that is easy to learn but requires special training. Student climbers were taught by professional arborist Charly Pottorff and Kenneth Snell and each climber was accompanied by a ground crew member who monitored safety. Suitable climbing trees were free of dead branches, thorns, and poison ivy, Toxicodendron radicans (L.) Kuntze. A giant slingshot (Sherrill Tree, Greensboro, North Carolina) was used to launch a pellet-weighted throw bag and slickline over the desired limb. This was attached to the climbing rope and pulled over the limb. Climbers wore an arborist's saddle and "tied in" by anchoring one end to the saddle and tying a friction knot, using a split-tail, to the running end.

Height in trees was measured using a reelbound altitude tape attached to the climbing saddle. Each tree was given a unique identifying number which referred to both the tree and grapevine. A small tag with the identification number was attached to the tree approximately 6-10 $\mathrm{m}$ in height on the opposite side of the tree from the trail or road, out of direct line of sight. Ground crew members were responsible for recording a datasheet of information with tree identification number, tree species, Universal Transverse Mercator coordinates, elevation, tree and grapevine $\mathrm{DBH}$, height of the tree, and general observations such as weather conditions and proximity to geographic features (streams, rocky outcroppings, trails, etc.).

Leaf collection was often extremely difficult in mature forest with dense canopy where no sucker shoots or non-woody vines were in reach. In many cases even the small diameter, woody side-branching vines that extended to the upper canopy were so well incorporated into the canopy that climbers were not able to pull them down even when transferring total body weight to the vine by hanging or standing on it. These difficulties usually required that the climber advance to the original point of rope installation and free climb to the top of the tree. Free climbing is when the climber disengages the climbing rope and uses a $3 \mathrm{~m}$ adjustable lanyard to climb up and secure the climbing rope at successively higher branches. This never required the climber to be untied from the tree but did require climbing among the branches. Free climbing is not possible in trees lacking suitable branching architecture in the upper canopy. At the top of the tree, grapevine leaves were easy to collect from the outer canopy.

Small grapevines that were out of reach to the climber in the upper canopy could also be collected by using a pellet weighted throw bag attached to a short section of slickline rope to hook and pull in these vines. In this manner, the small diameter, non-woody vines that hung down from the crown of the tree were targeted. The throw bag was rhythmically swung on slickline hanging below the climber until it gained enough momentum to be swung up and looped around the vine from the underside. Then the climber could pull the grapevine out of the canopy and into reaching distance. It was cautioned that if the targeted vine was too well integrated within the upper canopy or if the line was entangled in branches, the slickline and equipment would have to be severed and left, however, this never occurred.

Leaf voucher specimens were collected for both the tree and grapevine. Grapevines were often difficult to reach due to their growth habit, leafing out above the outer canopy of treetops, and collection of sucker leaves from the lower canopy was avoided due to the polymorphic variability of these leaves. To avoid damaging voucher specimens, they were often dropped to a member of the ground crew on the ground. However, there were various situations when the leaves would become entangled on lower branches or float away from the tree and entangle on nearby trees, out of reach of both the climber and ground crew member. To avoid these scenarios, specimens were placed in small paper bags to add weight and limit air drag created by the leaves. Another technique involved tucking specimens underneath 
clothing on the climber's back, where no damage to the specimen would occur. This technique was especially useful in cases where only a single leaf voucher was accessible and transport of the voucher to ground crew members was crucial. Leaf voucher specimens were placed in plastic bags immediately after collecting to reduce wilting and pressed within 8-12 hr after collection.

Tree species identifications were verified by Jay A. Raveill, University of Central Missouri, and grapevine identifications were verified by the current expert on Vitaceae, Jean M. Gerrath, University of Northern Iowa. Identification of grapevine species was more difficult, as there appears to be intergradations of taxonomic characters and paucity of characters based on dried, herbarium specimens. Due to these difficulties, a key to grapevine species was designed for identification of dried voucher specimens. The key was developed by using pressed and live specimens of known species that were collected and maintained by Gerrath. The key was a modification of the key to Vitis by Moore (1991) and was primarily developed by focusing on species known to occur in the study sites and by comparison of vouchers to dried specimens in the Gerrath collection.

Temporary labels were hand written on pressing papers with collection date, location, and tree identification number. After the species were identified, collection labels were type-written on bond paper with species name, collection location, neighboring tree species, habitat, UTM coordinates, elevation, collection date, collector's name, and tree identification number. Leaf voucher specimens are housed at the University of Central Missouri Plant Herbarium, Warrensburg, Missouri.

RESULTS Sixty trees were climbed and leaf vouchers of grapevines were collected, with many represented by more than one voucher specimen. Most of the vouchers were collected in GSMNP (32), 17 were collected in DBNF, 4 from BCF, and 7 from HAT. Over half of the grapevines were identified as $V$. aestivalis (35), 15 were $V$. vulpina, and 10 were not identified to species. Average neighboring tree height was approximately $25.7 \mathrm{~m}$. Mean diameter at breast height of grapevines was $9.6 \mathrm{~cm}$ for $V$. aestivalis and $8.9 \mathrm{~cm}$ for $V$. vulpina. Bark texture and thickness were evaluated for sampled bark and were highly variable within species of Vitis (Everhart et al. 2009). Therefore, bark characteristics were not considered as characters for identifications.

Grapevine species historically known to occur in the study areas based on county records within GSMNP (Cocke, Blount, and Sevier County, Tennessee), DBNF (Rockcastle, Madison, Pulaski, Clark, Powell, Wolfe, Menifee, Laurel, and Fayette County, Kentucky), BCF (Madison and Pulaski County, Kentucky), and HAT (Camden County, Missouri) are: Vitis aestivalis Michx., $V$. cinerea (Engelm. In A. Gray) Engelm. Ex Millardet., V. labrusca L., V. riparia Michx, $V$. rotundifolia Michx., and $V$. vulpina L. (Stupka 1964, Kurz 1997, Wofford and Chester 2002, Jones 2005, David Taylor pers. comm.). Vitis rupestris Scheele. is rare and only documented in Camden County, Missouri (Kurz 1997) and Laurel, Pulaski, and Wayne Counties, Kentucky (David Taylor pers. comm.). The following is a key to common grapevine species for GSMNP, DBNF, BCF, and HAT, modified from Moore (1991).

\section{MODIFIED KEY TO GRAPEVINE SPECIES}

1. Tendril or inflorescence at virtually every node.......... Vitis labrusca

1. Absense of tendril or inflorescense at every node............... 2

2. Distinct, conspicuous lenticels on woody stems . . . . . V V. rotundifolia

2. Inconspicuous lenticels on woody stems .............. 3

3. Glaucous coating on lower leaf surface, pubescence white to more commonly rusty orange in color ........ V. aestivalis

3. Absense of glaucous coating on lower leaf surface, pubescence mostly white but rarely rusty orange in color .......... 4 . 4. Lower leaf surface has slight to moderate arachnoid pubescence, varying to glabrous, veins covered in hirtellous trichomes and small tufts in vein axils ........ V. cinerea

4. Lower leaf surface has straight, hirtellous pubescence primarily along veins and axils, varying to glabrous .... . 5

5. Leaf margin is irregularly dentate-serrate, typically 
cordate at the base with cordiform blades; leaves often 3-shouldered to shallowly 3-lobed; shade leaves from lower canopy often deeply lobed .... V. vulpina

5. Leaf shape is cordiform cordate, 3-shouldered to shallowly 3-lobed, typically with 3 short acuminate apices to the lobes; the margin is sharply dentate-serrate..... V. riparia

Vitis aestivalis.-Blades cordiform cordate to orbicular, unlobed to 3-shouldered or 3-5 lobed, often deeply so; when lobed, they are mostly acute, with the sinuses rounded to acute. Leaf margins crenate to dentate, and upper surface of mature leaves glabrous to puberulent. Lower surface is glaucous with varying degrees of arachnoid, floccose pubescence, but when heavy the glaucescence is somewhat obscured; the pubescence whitish to more commonly rusty. Hirtellous trichomes are occasionally present along the veins and as tufts in the vein axils. Branchlets glabrous or have tomentose to arachnoid floccose pubescence. Tendril or inflorescense not present at every node. Glaucous coating may be present on nodes but will not be banded with red pigmentation.

Special note: This species is frequently confused with $V$. cinerea. However, the glaucous (blue to white waxy coating) leaf undersurface of pressed herbarium specimens easily distinguish $V$. aestivalis from $V$. cinerea but is not prominent in fresh specimens.

Ecological note: this species was often found in upland areas (D. Taylor pers. comm.).

Vitis cinerea.-Blades are cordiform, unlobed to 3-shouldered, and occasionally 3-lobed. Leaf margins are crenate to dentate; leaf apex acute to more commonly acuminate. Upper surface of mature leaves glabrous to pubescent, with hirtellous (straight) trichomes, thin arachnoid common. Lower leaf surface is not glaucous, with slight, to moderate arachnoid pubescence, varying to glabrous; the pubescence mostly whitish. Hirtellous trichomes also commonly present along the veins and as small tufts in the vein axils. Branchlets of the current season's growth are covered with dense, short, straight trichomes and/or thin to dense arachnoid pubescence, varying to glabrate. Nodes are not glaucous and often banded with red pigmentation.

Vitis vulpina.-Blades are cordiform, often 3shouldered to shallowly 3-lobed, deeply lobed only on ground shoot leaves. Leaf margins irregularly obtuse dentate-serrate, with bases typically cordate. Apex is acute to short acuminate. Upper surface of mature leaves is typically glabrous to very sparsely hirtellous pubescent, often lustrous or glabrous. Lower surface is green and characterized by short, straight hirtellous pubescence that occurs along the veins and in their axils, varying to more or less glabrous, rarely with very sparse arachnoid pubescence. Branchlets and emerging leaves glabrous to sparsely arachnoid pubescent; nodes not glaucous or banded with red pigmentation.

Ecological note: this species is commonly found in riparian areas (D. Taylor pers. comm.). This species was the largest grapevine sampled (20 cm DBH) and a record for DBNF, located in Menifee County, Kentucky.

\section{DISCUSSION}

Identification and Collection of Grapevines The modified key to species was developed because keys using characters of fresh specimens were not easily translated to dried vouchers. Examining all voucher specimens at one time revealed intergrading taxonomic characters, to the extent that all of the vouchers could have been arranged in order of the degree of similarity to form a full spectrum of characteristics. Duncan (1975) also notes that intergradations of taxonomic characters are most abundant between $V$. aestivalis, $V$. cinerea, and $V$. vulpina. Controlled experiments crossing species indicate hybridization is possible (Comeaux et al. 1987). However, hybridization in nature has not been studied. Some taxonomists recognize hybrids (Munson 1909, Duncan 1975, and Olmo 1976) whereas others do not (Bailey 1934, Comeaux et al. 1987). Comeaux et al. (1987) suggested that there may be geographical or phenological barriers that impede species hybridizations in nature. However, the results from this study find sympatric distribution of species and intergradations of 
morphological characters, suggesting hybridization and introgression is readily occurring naturally between $V$. aestivalis and $V$. vulpina. It was also suggested that the sympatric distribution of $V$. vulpina and $V$. riparia has also resulted in hybrids (David Taylor pers. comm.).

Leaves from the upper canopy that were produced in full sun were often strikingly different from leaves in the lower canopy that were produced in shade (shade leaves). Field identifications of shade leaves or bark characteristics were often incorrect, underscoring the need to collect leaf vouchers from the upper canopy. Mature grapevines that met the minimum sampling DBH of $4 \mathrm{~cm}$ were common on slopes in deep forest, presumably because the sloping nature would allow more access to light in the upper canopy. In many of these locations, no understory grapevines were observed and collection of any leaves in almost all of these locations was impossible from the ground. This leads the author to conclude that few studies, taxonomic or ecological, have included mature grapevines in deep forests.

The doubled rope climbing method is a superb method for accessing the upper canopy in mature forests because it is easy to learn and all of the necessary equipment can be carried to remote areas. Provided that the neighboring tree had suitable branch architecture for upper canopy access, it is expected that a skilled climber would be able to collect upper canopy leaf samples for 5 or more grapevines per day in mature forests with tree height over $35 \mathrm{~m}$.

\section{Suggested Studies}

Current research involving species of Vitis are investigating the broader phylogenetic relationships within the order Vitaceae (Jansen et al. 2006, Wen et al. 2007), basic studies on shoot architecture, morphology and anatomical development in Vitaceae (Gerrath and Posluszny 2007, Timmons et al. 2007), and extensive applied research related to commercial production of grapes (Lu et al. 2007a, 2007b, This et al. 2006). Although work by Moore and Giannasi (1994) examined foliar flavonoids as a possible character for species deliniations in North American Vitis, they would not be as useful in population studies. Indeed, no intensive studies of natural populations using molecular or genetic markers have been done, despite the availability of such markers that were developed for phylogenetic analyses of cultivated grapes (This et al. 1997, Lefort et al. 2002, Pelsy 2006, Huang et al. 2007, Aradhya et al. 2008).

The lack of studies on native Vitis species in North America is largely due to the difficulty in identifying species and inaccessibility of leaves in mature forests, which is a common reason for vines remaining relatively understudied in ecosystems (Putz and Mooney 1991). This research demonstrated the applicability of the doubled rope climbing method for collection of canopy climbing grapevines in mature forests that would otherwise be excluded from or not identified by researchers (Collins and Wein 1993, Morrissey et al. 2009). In addition, a simplified key to common Vitis species is presented to aid identification of dried, herbarium specimens, typically used in these types of studies. Ultimately, the doubled rope climbing collection method used in combination with traditional collection methods and currently available genetic markers will be essential in developing a better understanding of species hybridizations in nature and to delineate the distribution and occurrence of North American Vitis species.

ACKNOWLEDGMENTS This research was conducted as part of a master's thesis completed at the University of Central Missouri, under the direction of Harold W. Keller, whose guidance is gratefully and humbly acknowledged. Special thanks are due to Jean M. Gerrath and David Taylor, who both provided vital experience and insight regarding species identifications. Eldon R. Everhart is also gratefully acknowledged for his valuable reviews of this manuscript. Research was financially supported in part by the Willard North Graduate Research Award from University of Central Missouri to SEE, the National Science Foundation Biodiversity Surveys and Inventories Program DEB-0343447, Discover Life in America Award \#2002-17, and National Geographic Committee for Research and Exploration Award \#7272-02 to HWK. 


\section{LITERATURE CITED}

Aradhya, M., A. Koehmstedt, B.H. Prins, G.S. Dangl, and E. Stover. 2008. Genetic structure, differentiation, and phylogeny of the genus Vitis: Implications for genetic conservation. Acta Hort. (ISHS) 799:4349.

Bailey, L.H. 1934. The species of grapes peculiar to North America. Gentes Herb. 3:150-244.

Cohen, S.B. (ed.). 2000. The Columbia gazetteer of North America. Columbia University Press, New York, New York.

Collins, B.S. and G.R. Wein. 1993. Understory vines: distribution and relation to environment on a southern mixed hardwood site. Bull. Torrey Bot. Club 120:38-44.

Collins, R.F. 1975. A history of the Daniel Boone National Forest. United States Department of Agriculture, Forest Service, Atlanta, Georgia.

Comeaux, B.L., W.B. Nesbitt, and P.R. Fantz. 1987. Taxonomy of the native grapes of North Carolina. Castanea 52:197-215.

Duncan, W.H. 1975. Woody vines of the southeastern United States. University of Georgia Press, Athens, Georgia.

Everhart, S.E., H.W. Keller, and J.S. Ely. 2008. Influence of bark $\mathrm{pH}$ on the occurrence and distribution of tree canopy myxomycete species. Mycologia 100:191-204.

Everhart, S.E., J.S. Ely, and H.W. Keller. 2009. Evaluation of tree canopy epiphytes and bark characteristics associated with the presence of corticolous myxomycetes. Botany 87:509-517.

Gerrath, J.M. and U. Posluszny. 2007. Shoot architecture in the Vitaceae. Can. J. Bot. 85:691-700.

Gleason, H.A. and A. Cronquist. 1991. Manual of the vascular plants of northeastern United States and adjacent Canada, 2nd ed. The New York Botanical Garden Press, New York, New York.

Hopkins, B. 1996. The Smithsonian guides to natural America: Central Appalachia-West Virginia, Kentucky, and Tennessee. Smithsonian Books, New York, New York.
Huang, H., J. Lu, W.B. Hunter, and S.E. Dowd. 2007. Vitigene: a databse for grape genomics and genetic resources delivery that benefits grape growers and scientific communities. In: Proceedings of the 2007 College of Engineering Sciences, Technology and Agriculture Research Symposium, October 25, 2007, Tallahassee, Florida.

Jansen, R.K., C. Kaittanis, L. Seung-Bum, C. Saski, J. Tomkins, A.J. Alverson, and H. Daniel. 2006. Phylogenetic analyses of Vitis (Vitaceae) based on complete chloroplast genome sequences: Effects of taxon sampling and phylogenetic methods on resolving relationships among rosids. BCM Evolutionary Biol. 6:32.

Jepson, J. 2000. The tree climber's companion. Beaver Tree Publishing, Longville, Minnesota.

Jones, R.L. 2005. Plant life of Kentucky: an illustrated guide to the vascular flora. University Press of Kentucky, Lexington, Kentucky.

Kilgore, C.M., H.W. Keller, S.E. Everhart, A.R. Scarborough, K.L. Snell, M.K. Skrabal, C. Pottorff, and J.S. Ely. 2008. Tree canopy research and student experiences using the doubled rope climbing method. J. Bot. Res. Inst. Texas 2:1309-1336.

Kurz, D.R. 1997. Shrubs and woody vines of Missouri. Conservation Commission of the State of Missouri, Jefferson City, Missouri.

Lefort, F., C.J. Kyvelos, M. Zervou, K.J. Edwards, and K.A. Roubelakis-Angelakis. 2002. Characterization of new microsatellite loci from Vitis vinifera and their conservation in some Vitis species and hybrids. Molec. Ecol. Notes 2:20-21.

Lu, J., H. Huang, C. Louime, S. Xu, Z. Ren, F. Bradeley, W.B. Hunter, and P.M. Dang. 2007a. Using functional genomics approaches for identification, isolation and characterization of genetic targets: a case study of disease/pest resistant genes from native North American grape species (Vitis L.). In: Proceedings of the 2007 College of Engineering Sciences, Technology and Agriculture Research Symposium, October 25, 2007, Tallahassee, Florida. 
Lu, J., X. Xu, and Y. Jittayasothorn. 2007b. Establishment of efficient somatic embryogenesis and regeneration in muscadine grape (Vitis rotundifolia). Acta Hort. (ISHS) 738:773-778.

Martin, W.H., S.G. Boyce, and A.C. Echternacht (eds.). 1993. Biodiversity of the southeastern United States. John Wiley and Sons, Inc., New York, New York.

Moore, M.O. 1985. A systematic study of selected Vitis taxa in the southeastern United States. M.S. thesis, University of Georgia, Athens, Georgia.

Moore, M.O. 1991. Classification and systematics of eastern North American Vitis L. (Vitaceae) North of Mexico. Sida 14:339367.

Moore, M.O. and D.E. Giannasi. 1987. Foliar flavonoids of selected Vitis taxa in the southeastern United States. Biochem. Syst. Ecol. 15:79-83.

Moore, M.O. and D.E. Giannasi. 1994. Foliar flavonoids of eastern North American Vitis (Vitaceae) north of Mexico. Plant Syst. Evol. 193:21-36.

Morrissey, R.C., M.M. Gauthier, J.A. Kershaw, D.F. Jacobs, J.R. Seifert, and B.C. Fischer. 2009. Grapevine (Vitis spp.) dynamics in association with manual tending, physiography, and host tree associations in temperate deciduous forests. For. Ecol. Manage. 257:1839-1846.

Munson, T.V. 1909. Foundations of American grape culture. Orange Judd Publishing Company, New York, New York.

Olmo, H.P. 1976. Grapes: Vitis, Muscadinia (Vitaceae). p. 294-298. In: Simonds, N.W. (ed.). Evolution of crop plants. Longman, New York, New York.

Pelsy, F. 2006. Untranslated leader region polymorphism of $T v v 1$, a retrotransposon family, is a novel marker useful for analyzing genetic diversity and relatedness in the genus Vitis. Theor. Appl. Genet. 116:15-17.

Perry, J. 2000. A century of forestry at Berea College. Berea College Printing Services, Berea, Kentucky.
Putz, F.E. and H.A. Mooney (eds.). 1991. The biology of vines. Cambridge University Press, Cambridge, Massachusetts.

Read, P.E. and S. Gu. 2003. A century of American viticulture. HortScience 38:943-951.

Shanks, R.E. 1954. Climates of the Great Smoky Mountains. Ecology 35:354-361.

Snell, K.L. and H.W. Keller. 2003. Vertical distribution and assemblages of corticolous myxomycetes on five tree species in the Great Smoky Mountains National Park. Mycologia 95:565-576.

Southworth, S., A. Shultz, and D. Denenny. 2005. Generalized geologic map of bedrock lithologies and surfacial deposits in the Great Smoky Mountains National Park Region, Tennessee and North Carolina. Open-File Report 2004-1410 Version 1.0. United States Geological Survey, Reston, Virginia.

Stupka, A. 1964. Trees, shrubs, and woody vines of Great Smoky Mountains National Park. University of Tennessee Press, Knoxville, Kentucky.

This, P., C. Cuisset, and J.M. Boursiquot. 1997. Development of stable RAPD markers for the identification of grapevine rootstocks and the analysis of genetic relationships. Amer. J. Enol. Vitic. 48:492-501.

This, P., T. Lacombe, and M.R. Thomas. 2006. Historical origins and genetic diversity of wine grapes. Trends in Genet. 22:511-519.

Timmons, S.A., U. Posluszny, and J.M. Gerrath. 2007. Morphological and anatomical development in the Vitaceae IX. Comparative ontogeny and phylogenetic implications of Vitis rotundifolia Michx. Can. J. Bot. 85:850-859.

Webb, L. 2004. Ha Ha Tonka State Park. Missouri Resources 21:20-22.

Wen, J., Z. Nie, A. Soejima, and Y. Meng. 2007. Phylogeny of Vitaceae based on the nuclear GAI1 gene sequences. Can. J. Bot. 85:731-745.

Wofford, B.E. and E.W. Chester. 2002. Guide to trees, shrubs, and woody vines of Tennessee. University of Tennessee Press, Knoxville, Kentucky. 